\title{
PEMBERDAYAAN LINGKUNGAN MELALUI PROGRAM PENYEDIAAN AIR MINUM DAN SANITASI BERBASIS MASYARAKAT(PAMSIMAS) DESA PADANG MUTUNG KAMPAR
}

\author{
Yefni, Muhammad Haris \\ Prodi Pengembangan Masyarakat Islam UIN Suska Riau \\ Prodi Pengembangan Masyarakat Islam UIN Suska Riau \\ yefni.fdik@uin-suska.ac.id
}

\begin{abstract}
Abstrak
Penelitian ini bertujuan untuk mengetahui implemetasi Program Penyediaan Air Minum dan Sanitasi Berbasis Masyarakat (PAMSIMAS) pada masyarakat Desa Padang Mutung. Penelitian menggunakan metode kualitatif, pengumpulan data menggunakan observasi, wawancara dan peninjauan dokumen. Hasil penelitian menjelaskan Program PAMSIMAS melakukan sosialisasi sanitasi lingkungan yaitu, penyampaian materi dan pemahaman kondisi limgkungan Desa Padang Mutung kemudian melakukan aksi praktis bersih-bersih perkarangan rumah hingga DAS. Ke dua, melakukan kegiatan praktis yaitu, partisipasi aktif masyarakat menggali dan menyambung pipa-pipa air bersih ke rumah warga. Selanjutnya kondisi lingkungan masyarakat pra-Program PAMSIMAS membutuhkan perbaikan sanitasi yang ditandai dengan macetnya saluran irigasi dan tercemarnya aliran sungai akibat limbah rumah tangga. Adapun kondisi lingkungan masyarakat pascaprogram PAMSIMAS, sanitasi lingkungan menjadi lebih baik, ditandai dengan kepedulian masyarakat terhadap sampah, aktifitas MCK yang baik dan masyarakat memperoleh air dengan mudah.
\end{abstract}

Kata kunci: Pemberdayaan Lingkungan, Program PAMSIMAS

\section{Abstract}

This study aims to determine the implementation of Community-Based Water Supply and Sanitation Provisioning Programs (PAMSIMAS) in Padang Mutung Village community. Research using qualitative methods, data collection using observation, interviews and document review. The results of the study explained that the PAMSIMAS Program promotes environmental sanitation, namely, the delivery of material and an understanding of the environmental conditions of the Padang Mutung Village and then undertakes practical actions to clean up the houses from the river to the Watershed. Second, carrying out practical activities, namely, active community participation in digging and connecting clean water pipes to residents' homes. Furthermore, the environmental conditions of the pre-PAMSIMAS community program require improvement in sanitation, which is marked by irregularities in irrigation channels and pollution of river flow due to household waste. As for the environmental conditions of the people after the PAMSIMAS program, environmental sanitation has become better, marked by the community's concern for waste, good washing and toilet activities and the community gets water easily.

Keywords: Environmental Empowerment, PAMSIMAS Program

\section{Pendahuluan}

Tidak dapat dipungkiri, proses pembangunan senantiasa bertumpu pada pengelolaan dan pengolahan sumber-sumber daya (resources). Hampir negara-negara di dunia mengandalkan potensi sumber daya alam dipergunakan untuk meningkatkan 
kesejahteraan rakyat, tetapi memunculkan persoalan sanitasi yang merusak keberadaan ekosistem. Selain itu, etika negatif masyarakat terhadap lingkungan seringkali merusak ekosistem yang ada. Salah satu diantaranya yaitu air merupakan sumber daya yang urgen bagi kehidupan manusia. Banyak kegiatan manusia bergantung dengan ketersediaannya, baik ketersediaan air dari segi kualitas maupun kuantitas. ${ }^{1}$ Namun, semakin bertambahnya jumlah penduduk ancaman terhadap kualitas dan kuantitas sumber daya air semakin meningkat bahkan menjadi persoalan lingkungan.

Penyediaan air bersih memiliki peranan yang sangat penting dalam meningkatkan kesehatan lingkungan, yakni berperan dalam menurunkan kerusakan lingkungan, khususnya yang berhubungan dengan air serta berperan dalam meningkatkan taraf hidup masyarakat. Upaya yang mesti dilakukan adalah pendekatan yang berbasis masyarakat, berorientasi pencegahan, kerja sama dengan stakeholder, melibatkan masyarakat, serta pengorganisasian. ${ }^{2}$ Berbasis masyarakat adalah upaya bersama-sama menyadarkan masyarakat tentang pentingnya menjaga sanitasi lingkungan, mengupayakan perbaikan terhadap lingkungan yang rusak dan menyediakan model baru untuk mengatasi persoalan yang ada. Selain itu, upaya kesehatan masyarakat harus diterapkan pada kelompok masyarakat tanpa membedakan faktor umur, ras, agama, jenis kelamin atau jenis pengelompokan lainnya, baik dalam satu wilayah RT dan RW bahkan suatu negara, semua harus memiliki kesamaan untuk dilindungi secara adil tanpa membedakan. ${ }^{3}$

Air dan sanitasi lingkungan merupakan sektor terpenting pemerintah dalam rangka peningkatan taraf hidup masyarakat. Program Penyediaan Air Minum dan Sanitasi Berbasis Masyarakat (PAMSIMAS) adalah program melibatkan berbagai stakeholder baik yang berada di tingkat pusat, provinsi maupun daerah. Program dukungan dari Bank Dunia ini melibatkan berbagai unsur-unsur yang ada di pemerintah antara lain Bappenas, Departemen Pekerjaan Umum, Departemen Dalam Negeri dan Departemen Keuangan. Prinsipnya berbasis masyarakat, artinya peran aktif masyarakat menjadi faktor penentu keberhasilan dalam pelaksanaan program ini.

${ }^{1}$ Robert J. Kodoatie,Pengelolaan Sumberdaya Air Dalam Otonomi Daerah,(Yogyakarta: ANDI,. 2002), h. 1

${ }^{2}$ Umar, Fahmi Achmadi, Kesehatan Masyarakat Teori Dan Aplikasi, (Jakarta: Rajawali, 2016 Pers), h. 10-15

${ }^{3}$ Ibid, h. 10-11 
Program PAMSIMAS di Desa Padang Mutung adalah kegiatan yang dilakukan oleh Kementerian Pekerjaan Umum sebagai executing agency bersama dengan Kementerian Dalam Negeri Dan Kementerian Kesehatan ${ }^{4}$ menggunakan pendekatan berbasis kelembagaan, Stakeholder perusahaan daerah serta berbasis masyarakat dengan menempatkan masyarakat sebagai pelaku utama dan penentu dalam penyelenggaraan pelayanan, melalui proses pemberdayaan dan partisipasi aktif masyarakat..$^{5}$ Tujuannya agar sanitasi lingkungan masyarakat menjadi sehat, air disungai mengalir dengan deras tanpa dicemari oleh limbah apapun dan terpenuhinya kebutuhan air untuk semua aktifitas masyarakat setiap waktu.

Dari latar belakang tersebut, penelitian ini fokus permasalahan utama yang akan di kaji adalah bagaimanakah implementasi Program Penyediaan Air Minum dan Sanitasi Berbasis Masyarakat (PAMSIMAS) pada masyarakat?

\section{Metode Penelitian}

Penelitian ini menggunakan pendekatan kualitatif, mengumpulkan data atau informasi berdasarkan fakta yang ada pada objek penelitian. Kemudian memaparkan semua fenomena yang tampak, selanjutnya data tersebut di analisa dan dikaji secara konfrehensif untuk menemukan kesimpulan akhir. ${ }^{6}$ Dalam penelitian ini peneliti memahami fenomena yang terjadi dalam proses pemberdayaan dengan melakukan interaksi antara peneliti dan informan dalam memperoleh data untuk selanjutnya dideskrifsikan.

Penelitian kualitatif digunakan untuk mengenal dan memahami subjek penelitian secara pribadi dan kelompok. Ciri penelitian kualitatif mewarnai sifat dan bentuk laporannya disusun dalam bentuk narasi yang bersifat kreatif dan mendalam. ${ }^{7}$ Penelitian kualitatif dipilih karena untuk menjelaskan secara konfrehensif terkait pemberdayaan lingkungan.

Penelitian lapangan ini akan dilakukan pada masyarakat Desa Padang MutungKampar. Alasan mengambil lokasi ini pertimbangan secara akademik, yaitu: desa ini

${ }^{4}$ Petunjuk Teknis Pemantauan, Evaluasi, Dan Pelaporan, Penyediaan Air Minum Dan Sanitasi Berbasis Masyarakat, (Kampar: 2011), h. 1

5 Departemen Pekerjaan Umum, "Pedoman Teknis Pelaksanaan Program PAMSIMAS di Masyarakat." Program Penyediaan Air Minum dan Sanitasi Berbasis Masyarakat, (Jakarta: 2011), h. 8

${ }^{6}$ Hadari Nawawi dan Mimi Martini, Penelitian Terapan, (Yogyakarta: Gajah Mada University Press, 1994), h. 73

${ }^{7}$ Nurul Zuriah, Metodologi Penelitian Sosial dan Pendidikan, (Jakarta: Bumi Aksara, 2005), h. 92 
pertama kali penerima Program PAMSIMAS tahun 2013 dengan melibatkan partisipasi masyarakat.

Objek dalam penelitian ini adalah pemberdayaan lingkungan melalui Program Penyediaan Air Minum dan Sanitasi Berbasis Masyarakat (PAMSIMAS). Data yang akan digali adalah implementasi Program Penyediaan Air Minum dan Sanitasi Berbasis Masyarakat (PAMSIMAS).

Informan yang dipilih adalah informan yang dirasa mampu untuk memberikan banyak informasi berkaitan dengan objek penelitian dan diperkirakan akan memperlancar proses penelitian. ${ }^{8}$ Penentuan informan penelitian ini menggunakan teknik purpossive sampling, yaitu teknik yang digunakan ketika peneliti mempunyai pertimbangan tertentu dalam penentuan infoman. ${ }^{9}$ Artinya peneliti tidak membatasi jumlah infoman selama data yang diperoleh menjawab permasalahan penelitian.

Pemilihan informan dalam penelitian ini dilakukan untuk menjaring sebanyak mungkin informasi dari berbagai macam sumber dan menggali informasi yang akan menjadi dasar dari rancangan dan teori yang dibangun. Informan dalam penelitian ini terbagi menjadi dua, yaitu: pertama, informan pengamat adalah pihak kemetrian PU, Stakeholder dan kepala desa beserta staf. Kedua, informan terlibat adalah praktisi dan masyarakat.

Untuk memperoleh data yang berkaitan dengan masalah penelitian, juga melakukan observasi, dilakukan pengamatan secara orang luar. Selanjutnya mewawancarai informen untuk memperoleh sebanyak mungkin data. Wawancara dalam penelitian ini dilakukan dengan menggunakan pedoman wawancara agar prosesnya lebih terarah dan tidak melenceng dari rancangan yang telah dibuat. Satu pertanyaan kemudian dikembangkan sampai tidak memunculkan pertanyaan lagi tentang satu persoalan. Wawancara ini berguna untuk menggali data dan informasi tentang proses pemberdayaan serta tujuannya sehingga diperoleh data yang menjawab permasalahan dalam penelitian ini. Terakhir melakukan analisa bertujuan untuk mengkaji dan memahami informasi dan fenomena-fenomena yang telah terkumpul. Data yang

${ }^{8}$ Iskandar, Metodologi Penelitian Pendidikan dan Sosial, (Kuantitatif dan Kualitatif), (Jakarta : Gaung Persada Press, 2008), h. 219

${ }^{9}$ Sugiyono, Metode Penelitian Kualitatif, Kualitatif dan R\&D, (Bandung: Alfabeta, 2009), h. 218 
terkumpul akan dianalisis melalui berbagai proses yang akan dilalui yaitu melalui tahap model air ${ }^{10}$ yaitu:

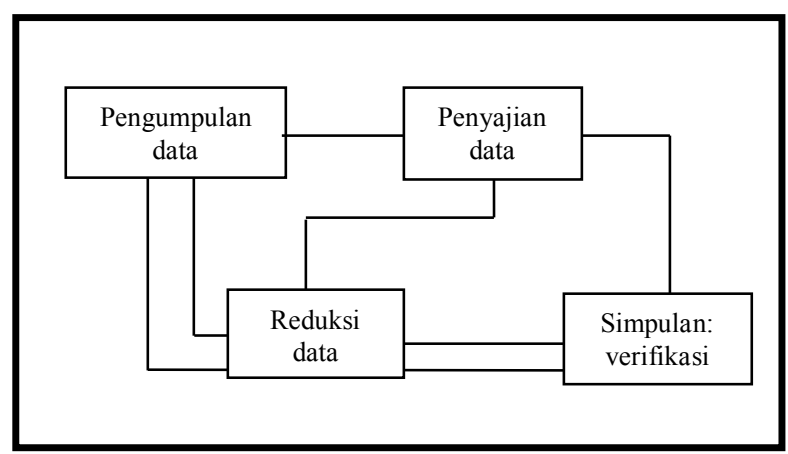

Untuk menguji keabsahan data dilakukan teknik triagulasi (cross cheek) antara lain triagulasi sumber, yaitu proses triangulasi yang dilakukan dengan sistem berlapis, maksudnya adalah satu pertanyaan terkait proses pemberdayaan ditanyakan kepada setiap informan yang menjadi sumber informasi data dan teori yang terkait dengan penelitian ini. Proses triagulasi dilakukan secara terus menerus sepanjang proses pengumpulan data, analisis data, sampai diyakini tidak perlu konfirmasi kepada informan lagi. Triagulasi dilakukan menguji pemahaman peneliti dengan pemahaman informan. ${ }^{11}$ Data yang telah diuji keabsahannya melalui pemeriksaan terhadap sumber data dan teori kemudian ditarik kesimpulan.

\section{Hasil dan Pembahasan}

Pemerintah menyadari bahwa untuk mencapai taraf hidup masyarakat yang lebih baik, pembangunan tidak saja disisi ekonomi, melainkan pembangunan wilayah masyarakat juga dibutuhkan. Pembanguan disisi ekonomi saja tanpa diikuti oleh pembangunan lingkungan atau disisi yang lain adalah suatu hal yang mustahil dimunculkan kehidupan yang lebih baik. Munculnya paradigma pembangunan yang ramah lingkungan dan bersifat sistinable, bisa dijadikan alasan bahwa kegiatan pembangunan selama ini memang kurang memperhatikan resiko ketersedian sumber daya dan lingkungannya sebagai suatu ekosistem. Dalam paradigma pembangunan seperti geocentric paradigm dan anthropocentris paradigm seperti yang telah dijelaskan

${ }^{10}$ Burhan Bungin, Analisa Data Penelitian Kualitatif Pemahaman Filosofis dan Metodologis Kearah Penguasaan Model Aplikasi, (Jakarta: PT. Raja Grafindo Persada, 2003), h. 144-145

${ }^{11}$ Ibid, h. 192 
oleh Hasim dan Remiswal ${ }^{12}$ yaitu paradigma tersebut telah memicu tindakan ekplorasi dan ekploitasi sumber daya secara besar besaran dan menempatkan nafsu serakah manusia untuk mengeruk keuntungan sesaat tanpa disengaja telah merampas hak-hak generasi selanjutnya.

Lebih lanjut dijelaskan Salmadanis, ${ }^{13}$ kondisi lingkungan sangat mempengaruhi kehidupan manusia, baik dalam bentuk upaya pemenuhan kebutuhan ekonomi, pendidikan, sosial budaya, maupun sikap dan perilaku lainnya. Di sisi lain, manusia juga dapat mempengaruhi keadaan lingkungan yang sudah ada disekitarnya. Manusia merubah situasi ataupun kondisi lingkungan sesuai dengan keinginan atau kebutuhannya. Dengan demikian jelaslah bahwa lingkungan mempengaruhi kehidupan manusia dan manusiapun dapat mempengaruhi kondisi lingkungan dimana mereka berada sesuai dengan keinginan dan kebutuhan manusia itu sendiri.

Kemudian, kehidupan manusia tidak dapat dipisahkan dengan lingkungan, karena kapan saja dan dimana saja manusia berada, ia tetap behubungan dengannya. Lingkungan adalah sebuah tempat manusia hidup, manusia tinggal di dalamnya, baik ketika berpergian ataupun mengasingkan diri. Lingkungan juga sebagai tempat manusia kembali, baik dalam keadaan rela ataupun terpaksa. Hal tersebut menunjukan bahwa dimana saja manusia berada, akan berhadapan dengan lingkungan baik lingkungan yang dinamis maupun statis.

Untuk mencukupi segala kebutuhan air dan tertatanya sanitasi lingkungan pemerintah merencanakan program PAMSIMAS, tidak semua desa mendapatkan program ini. Ada beberapa indikator yang menjadi acuan dalam pelaksanaanya. Program PAMSIMAS di Desa Padang Mutung di awali dengan sosialisasi program di tingkat kabupaten. Kemudian pemerintah kabupaten mengajukan daftar desa/kelurahan calon lokasi sasaran program yang memenuhi kriteria pra kualifikasi yaitu:

1. Tinggi tingkat kemiskinan

2. Rendahnya fasilitas air bersih dan sanitasi

3. Tingginya penderita diare

4. Tidak menerima bantuan program sejenis setidaknya 2 tahun terakhir.

${ }^{12}$ Hasim dan Remiswal, Community Development Berbasis Ekosistem, (Jakarta: Diadit Media, 2009), h. 115

13 Salmadanis, Standar Kompetensi Pelaku Dakwah(Dialektika Metode dan Model Dakwah Kreatif), (Padang: Imam Bonjol Press, 2014), h. 197 
Kemudian difasilitasi kepala desa untuk diadakanlah musyawarah Desa memutuskan keikutsertaan Desa dalam Program PAMSIMAS. Pertimbangan yang mendasar bahwa Desa Padang Mutung mengalami kekurangan dalam sarana pemenuhan kebutuhan air bersih untuk keperluan sehari-hari, saat musim kemarau sebagian besar masyarakat yang menggunakan air sumur dilanda kekeringan dan kerusakan sanitasi lingkungan membuat masyarakat tidak sehat. ${ }^{14}$

Sebelum adanya Program PAMSIMAS, sanitasi lingkungan masyarakat dalam kondisi yang memerlukan perbaikan, seperti saluran irigasi atau drainase yang tersumbat, lebih besarnya saluran sungai dicemari sampah rumah tangga, pendangkalan aliran sungai akibat sedimen dan material yang dibuang kedalamnya ditambah lagi denga kegiatan MCK dilakukan di sungai, rata-rata air sumur warga keruh dan kering di musim kemarau. Kondisi yang demikian tidak jarang masyarakat terjangkit diare, dan gatal-gatal pada balita/anak-anak bahkan orang dewasa. Hal ini disebabkan karena sumber air masyarakat banyak yang kering, sehingga masyarakat menggunakan air sungai untuk diminum, mencuci dan mandi. ${ }^{15}$

Berbagai persolan di atas disebabkan oleh faktor tertentu, menurut Harun Nasution ${ }^{16}$ faktor-faktor yang membawa kepada perusakan dan pencemaran lingkungan hidup akan kelihatan bahwa sebab pokoknya terletak pada materialisme yang melanda dunia dewasa ini. Manusia berlomba-lomba untuk mendapatkan kesenangan materi sebanyak mungkin. Orang berkeyakinan semakin banyak materi yang dimilikinya, maka ia akan menjadi semakin senang dan bahagia. Dalam mengumpulkan kekayaan materi, orang tidak segan menebang hutan, menjaring sebanyak mungkin ikan-ikan di laut, menguras barang mineral dari perut bumi, membuang limbah ke air dan udara.

Selanjutnya, agar berbagai persoalan teratasi dan kondisi yang saling membutuhkan serta mempengaruhi tersebut tidak mengarah kepada terjadinya kerusakan yang selanjutnya juga akan menyengsarakan bagi masyarakat, semestinya perlu arah atau pedoman sebagai rujukan bagi manusia dalam menjalankan kehidupan agar memiliki etika dan estetika terhadap lingkungan, dan Islam telah memberikan jalan untuk manusia kearah tersebut.

\footnotetext{
${ }^{14}$ Rencana Kerja Masyarakat Buku II, Desa Padang Mutung, (Kampar: 2011), h. 1

${ }^{15}$ Progam Jangka Menengah, Penyediaan Air Minum, Kesehatan, Dan Sanitasi (PJM Pro-Aksi), h

${ }^{16}$ Ibid, h. 206
} 1 
Adapun etika atau sikap(perilaku) manusia terhadap lingkungan yaitu;

1. Tidak merusak ciptaan Allah

Maksudnya adalah tidak mengubah fitrah manusia dan segala sesuatu yang telah diciptakan Allah. Orang yang mengubah air yang diturunkan Allah dari langit berupa air hujan yang suci menjadi air yang tercemar dengan limbah-limbah industri lainnya, maka ia telah mengubah fitrah dan ciptaan Allah. Orang yang mengubah tanah untuk bercocok tanam dan layak sebagai tempat tinggal bagi penghuninya menjadi bumi yang terancam dengan segala kerusakan dan keguncangan dari segala arah, maka ia telah mengubah fitrah dan ciptaan-Nya.

\section{Tidak berbuat kezaliman}

Perbuatan zalim adalah perbuatan yang berbahaya, baik kezaliman kepada dirinya sendiri, kepada saudara-saudaranya atau kezaliman manusia kepada lingkungan dengan segala unsur komponennya yang beragam, dari hewan, tumbuhan, benda-benda padat, tanah, air, udara dan lain sebagainya. Tindakan zalim itu seperti pembakaran hutan, pencurian hutan, pembuangan limbah dan lain-lain.

3. Tidak sombong di muka bumi

Kesombongan akan membawa pelecehan kepada orng lain dan lingkungan sekitarnya. Seperti menginjak-injak rerumputan yang memang disana tidak ada keperluan manusia dalam mencari nafkah. Tidak sombong berarti selalu melihat bahwa segala sesuatu yang telah ada ini sebagai sesuatu yang telah diberikan Tuhan untuk manusia yang mesti dijaga keseimbangannya.

4. Tidak menuruti hawa nafsu

Nafsu bisa menguasai manusia dan menjadikan manusia tidak terhormat. Lingkungan rusak banyak disebabkan karena tunduknya manusia kepada hawa nafsu dan mementingkan kepuasan syahwatnya serta hasrat duniawinya.

5. Menjaga keseimbangan kosmos

Segala yang ada dan tampak ini diciptakan Allah dengan penuh keseimbangan dan ukuran yang jelas. Seperti dalam firman Allah dalam surat $A r-R a$ 'd : 8 yaitu: dan segala sesuatu pada sisinya ada ukurannya.Kerusakan yang terjadi di muka bumi merupakan akibat dari perbuatan manusia yang melampauwi batas keadilan dan kecenderungan manusia pada kewenangan-kewenangan. Manusia dituntut untuk adil 
terhadap lingkungan dan segala komponennya yang beragam tanpa berbuat semenamena dan sewenang-wenang dalam timbangan yang tidak lebih dan tidak kurang. Semuanya tepat pada tempatnya secara porposional.

6. Bersyukur atas nikmat dan karunia Allah

Bersyukur berarti menerima semua yang telah diberikan Allah sebagai sesuatu yang dianugerahkan kepadanya dengan tanpa merusaknya dan memeliharanya serta menjaganya sebagai sesuatu yang dimiliki dan menganggap pemberian Tuhan yang paling berharga. Lingkungan yang begitu luas beserta isinya seperti tumbuhan yang mengahsilkan buah-buahan, kayu dan batu untuk bangunan rumah, energi mineral untuk diminum dan energi tambang lainnya yang dipergunakan untuk bahan baku dalam memenuhi kebutuhan

Melalui Program PAMSIMAS, masyarakat dapat memprioritaskan air bersih dan sanitasi, karena meskipun mereka berada pada ekonomi menengah kebawah, melalui berbagai kemudahan tersebut mereka tetap bisa mengakses fasilitas air dan sanitasi untuk keberlangsungan hidup. Adapun implementasi pemberdayaan lingkungan melalui Program PAMSIMAS yaitu mengembangkan perilaku masyarakat terhadap lingkungan melalui dua bentuk kegiatan pertama: sosialisasi tentang pentingnya menjaga lingkungan. Tugas utama dilakukan oleh dinas kesehatan melalui kepada desa dan ketua RT dan RW untuk mengajak masyarakat berkumpul di dusun masing-masing untuk mendapatkan penjelasan terkait kondisi lingkungan di Desa tersebut. Diketahui kondisi yang ada memiliki sanitasi lingkungan yang memerlukan perbaikan. Persoalannya adalah sampah yang tidak memiliki tempat pembuangan, sebagian dibuang ke sungai sehingga menyebabkan air sungai dicemari sampah ditambah lagi oleh limbah rumah tangga dan kegiatan MCK semuanya dialirkan kesungai. Tentu hal ini menyebabkan pendangkalan DAS oleh sedimen-sedimen limbah, disamping sebagaian masyarakat masih menggunakan air sungai sebagai konsumsi. Kondisi demikian juga menyebabkan diare. Kemudian menyampaikan rincian program yang akan dibangun di Desa Padang Mutung.

Selanjutnya, selain menyampaikan persoalan yang dihadapi, dinas terkait juga mengajak aksi bersih-bersih dan penataan perkarangan rumah setiap warga. Kemudian dilanjutkan kepasilitas umum dan pembersihan Daerah Aliran Sungai (DAS). Kegiatan 
ini dilakukan selama 8 hari yaitu setiap hari sabtu dan minggu. Kegiatan ini bermakna bahwa kebersihan lingkungan dimulai dari lingkungan kecil, yaitu rumah tangga.

Lebih lanjut, Pengembangan perilaku masyarakat dimulai dari menyadarkan mereka dengan lingkungan yang mereka temapati sebagai sesuatu yang mereka miliki sekarang dan butuh penjagaan agar mereka meiliki ketenangan dan hidup dengan nyaman untuk mereka dan generasi mereka. Kesadaran tumbuh dari diri mereka sendiri melalui pengertian yang diberikan oleh stake holder. Kesadaran yang datang dari diri mereka lewat pengertian dan latihan yang baik hasilnya sangat berbeda dengan kesadaran yang muncul dari keterpaksaan. Mereka berbuat tidak sepenuhnya berdasarkan keinginan, melainkan karena suatu pengaruh. Seperti yang dikatakan Jacobus Ranjabar, ${ }^{17}$ mengenai lingkungan kesadaran yang paling tinggi adalah manusia menyadari bahwa makhluk hidup lainnya bukan berdiri sendiri, tetapi dalam unsurunsur yang merupakan bagian dari sistem alam ini yang diciptakan Tuhan, satu sama lain berhubungan sesuai dengan fungsi dan peranan dalam sistem organisme.

Selanjutnya penyadaran dan pembentukan perilaku yang merupakan tahap persiapan dalam proses pemberdayaan masyarakat. Pada tahap ini pihak yang berdaya berusaha menciptakan prakondisi. Supaya dapat memfasilitasi berlangsungnya proses pemberdayaan yang efektif. Proses pemberdayaan masyarakat sesungguhnya mengintervensi kemampuan afektifnya untuk mencapai kesadaran kongnitif yang diharapkan. Sentuhan penyadaran akan lebih membuka keinginan dan kesadaran masyarakat tentang kondisinya saat itu, dengan demikian dapat merangsang kesadaran mereka tentang perlunya memperbaiki kondisi untuk menciptakan masa depan yang lebih baik. Dalam proses perlu ditemukan informasi dengan menggali langsung kepada masyarakat terkait permasalahannya.

Berkaitan dengan pelestarian lingkungan dalam tahap penyadaran dapat dilakukan dengan menyampaikan perlunya menjaga kebersihan. Dalam sebuah ungkapan disebutkan bahwasanya kebersihan sebagaian dari pada iman. Artinya orang yang menjaga dan memelihara lingkungan berarti dia telah menunjukan diri sebagai seorang yang beriman. Sebaliknya jika mengotori ligkungan dengan membuang sampah sembarangan, mengeksploitasi lingkungan dengan berlebihan berarti kadar imannya masih patut dipertanyakan. Selain itu juga menyebutkan dan memaparkan beberapa

${ }^{17}$ Jacobus Ranjabar, Sistem Sosial Budaya Indonesia Suatu pengantar, (Bogor: Ghalia Indonesia, 2006), h. 115 
dampak kerusakan yang disebabkan oleh tindakan masyarakat disertai contoh dalam bentuk dokumentasi jika terlalu berlebihan dalam menggunakan dan mengambil manfaat dari lingkungan. Tindakan lain yaitu mensosialisasikan tentang pembuangan sampah sembarangan dan dampaknya serta banyak lagi tindakan penyadaran lainnya

Kedua: pembangunan sumur bor air bersih. Proses pembanguan sumur bor di awali dari gerakan partisipasi masyarakat yang saling bekerjasama dan bergotong royong menggali tanah dan menyambung pipa-pipa air untuk dialirkan kesetiap rumah. Setiap warga saling membantu, menyumbangkan dana untuk menyukupi pipa yang yang kurang, sehingga tidak ada satupun rumah yang tidak aliri air. Proses pengeboran sumur bor dilakukan oleh pihak ketiga sebagai pekerja sumur bor, masyarakat sebagai pemantai dan mempercepat proses pengerjaan. Dalam waktu 4 hari sumur bor siap dan air siap dialirkan kerumah warga.

Pola yang demikian menyebutkan bahwa dalam proses pembangunan masyarakat diikutsertakan, artinya masyarakat tidak lagi sebagai objek, melainkan sebagai subjek pembangunan. Pola ini disebut juga dengan tahap praktis, Merupakan suatu tahap yang memberikan partisipasi aktif masyarakat dalam menjaga lingkungannya diwujutkan dalam bentuk tindakan praktis. Proses ini disebut proses transformasi pengetahuan dan ketrampilan sebagai tahap pelaksanaan dapat berlangsung dengan baik. Masyarakat menjalani proses belajar tentang pengetahuan dan keterampilan yang memiliki relevansi dengan tuntutan kebutuhan dan memecahkan permasalahan yang dialami. Kondisi seperti ini akan menstimulasi terjadinya keterbukaan wawasan dan menguasai keterampilan dasar yang mereka butuhkan.

Tindakan praktis dari proses transformasi dalam menjaga kelestarian lingkungan dapat dilakukan dengan cara membersihkan lingkungan dan selokan yang kotor, membuang sampah pada tempatnya, mengeksploitasi hutan dengan sewajarnya dan melakukan penanaman pohon dan penghijauan. Dalam sebuah sejarah Rasulullah mengajarkan kepada sahabatnya pentingnya menanam pohon dan menghijaukan lahan. Rasul mengatakan Apabila seorang muslim menanam tanaman kemudian tanaman itu dimakan oleh burung, manusia ataupun binatang, maka orang tersebut mendapat pahala bersedekah. (HR. Bukhari dan Muslim)

Supaya daya serap tanah semakin tinggi, maka tanah perlu dikelolah dengan baik, yaitu dibajak dan di pupuk. Islam juga menjarkan kepada umatnya agar menghidupkan 
lahan mati. Tujuannya agar tercipta keseimbangan lingkungan. Dalam penghidupan lahan mati, Rasulullah bersabda: siapa yang menghidupkan lahan tanah yang mati, maka tanah itu menjadi miliknya dan apabila diambil oleh para pencari rezeki, maka menjadi pahala sedekah untuknya. Maksud dari pencari rezeki adalah binatang buas, burung-burung, manusia, dan siapa saja yang memanfaatkannya.

Pasca pembangunan sumur bor air bersih, masyarakat sudah menikamti air dari setiap rumah dengan baik dan lancer, tidak ditemukan kendala dalam memperoleh air, terkadang masih ada problem kecil yaitu, persolan mesin pompa yang kadang suatu waktu bias rusa, namun hal tersebut sudah diantisipasi melalui gerakan gotong royong masyarakat dalam memperbaikinya. Selain memperoleh air dengan mudah, masyarakat sudah memperbaiki jamban dan kambar mandi disetiap rumah, sehingga kegiatan MCK tidak lagi terlihat di sungai. Beberapa penyakit seperti diare sudah mulai berkurang. Kondisi ini menyebutkan bahwa pasca berjalannya Program PAMSIMAS di Desa Padang Mutung sarana air bersih dan sanitasi lingkungan menjadi lebih baik. Hal itu juga membuktikan bahwa program PAMSIMAS memiliki pengaruh kepada masyarakat.

\section{Kesimpulan}

Mengacu kepada permasalahan penelitian, dapat disimpulkan bahwa implementasi Program Penyediaan Air Minum dan Sanitasi Berbasis Masyarakat (PAMSIMAS) pada masyarakat sebagai berikut: pertama, melakukan sosialisasi sanitasi lingkungan dalam bentuk penyampaian materi dan pemahaman kondisi limgkungan Desa Padang Mutung dan melakukan aksi praktis bersih-bersing perkarangan rumah hingga DAS. Ke dua, melakukan kegiatan praktis yaitu melibatkan partisipasi aktif masyarakat dalam menggali dan menyambung pipap-pipa air bersih ke rumah warga. Selanjutnya kondisi lingkungan masyarakat pra-Program PAMSIMAS membutuhkan perbaikan sanitasi yang ditandai dengan macetnya saluran irigasi dan tercemarnya aliran sungai akibat limbah rumah tangga. Sedangkan kondisi lingkungan masyarakat pascaprogram PAMSIMAS sanitasi lingkungan menjadi lebih baik, ditandai dengan masyarakat sudah membuang sampah pada tempatnya, aktifitas MCK ada disetiap rumah dan air mengalir disetiap rumah dengan lancer. 


\section{Referensi}

Achmadi Umar, Fahmi. 2016. Kesehatan Masyarakat Teori Dan Aplikasi. Jakarta: Rajawali Pers

Bungin Burhan. 2003. Analisa Data Penelitian Kualitatif Pemahaman Filosofis dan Metodologis Kearah Penguasaan Model Aplikasi. Jakarta: PT. Raja Grafindo Persada

Departemen Pekerjaan Umum. 2011. Pedoman Teknis Pelaksanaan Program PAMSIMAS di Masyarakat." Program Penyediaan Air Minum dan Sanitasi Berbasis Masyarakat. Jakarta

Hasim dan Remiswal. 2009. Community Development Berbasis Ekosistem. Jakarta: Diadit Media

Iskandar. 2008. Metodologi Penelitian Pendidikan dan Sosial, (Kuantitatif dan Kualitatif). Jakarta : Gaung Persada Press

Kilun Yusra, ed. 2007. Pengembangan Komunitas Muslim Kampung Badak Putih dan Kampung Duit. Jakarta: UIN Syarif Hidayatullah

Kodoatie, Robert J. 2002. Pengelolaan Sumberdaya Air Dalam Otonomi Daerah. Yogyakarta: ANDI

Mardikanto Totok. 2013. Pemberdayaan Masyarakat dalam Perspektif Kebiajakn Publik. Bandung: Alfabeta

Nasution Harun. 1989. Islam Rasional. Jakarta: LSAF

Nawawi Hadari dan Martini Mimi. 1994. Penelitian Terapan. Yogyakarta: Gajah Mada University Press

Petunjuk Teknis Pemantauan, Evaluasi, Dan Pelaporan. 2011. Penyediaan Air Minum Dan Sanitasi Berbasis Masyarakat. Kampar

Progam Jangka Menengah, Penyediaan Air Minum, Kesehatan, Dan Sanitasi (PJM ProAksi)

Ranjabar Jacobus. 2006. Sistem Sosial Budaya Indonesia Suatu pengantar. Bogor: Ghalia Indonesia

Rencana Kerja Masyarakat Buku II. 2011. Desa Padang Mutung. Kampar

Salmadanis. 2014. Standar Kompetensi Pelaku Dakwah(Dialektika Metode dan Model Dakwah Kreatif). Padang: Imam Bonjol Press 
Sugiyono. 2009. Metode Penelitian Kualitatif, Kualitatif dan R\&D. Bandung: Alfabeta

Sulthon Muhammad. 2003. Desain Ilmu Dakwah, Kajian Ontologis, Epistemologis dan Aksiologis. Semarang : Wali Songo Press

Zuriah Nurul. 2005. Metodologi Penelitian Sosial dan Pendidikan. Jakarta: Bumi Aksara 